\title{
Identification of species adulteration in traded medicinal plant raw drugs using DNA barcoding
}

\begin{tabular}{|r|l|}
\hline Journal: & Genome \\
\hline Manuscript ID & gen-2015-0225.R2 \\
\hline Manuscript Type: & Article \\
\hline Date Submitted by the Author: & 08-Jun-2016 \\
\hline Complete List of Authors: & $\begin{array}{l}\text { Stalin, Nithaniyal; SRM University, Genetic engineering } \\
\text { Vassou, Sophie ; SRM University, Genetic engineering } \\
\text { Sundar, Poovitha; SRM University, Genetic Engineering } \\
\text { Raju, Balaji; SRM University, Genetic Enineering } \\
\text { Madasamy, Parani; SRM University, Genetic Engineering }\end{array}$ \\
\hline Keyword: & $\begin{array}{l}\text { Medicinal plants, Species adulteration, Raw drug trade, DNA barcoding, } \\
\text { Complementary and alternative medicine }\end{array}$ \\
\hline &
\end{tabular}

SCHOLARONE $^{\text {It }}$

Manuscripts 


\title{
Identification of species adulteration in traded medicinal plant raw drugs using DNA barcoding
}

Stalin Nithaniyal, Sophie Lorraine Vassou, Sundar Poovitha, Balaji Raju, Madasamy Parani *

Department of Genetic Engineering, Center for DNA Barcoding, SRM University, Kattankulathur 603203, India.

${ }^{*}$ Corresponding author. Tel.: 091-44-27417817.

E-mail address: parani.m@ktr.srmuniv.ac.in (M. Parani).

\begin{abstract}
Plants are the major source of therapeutic ingredients in Complementary and Alternative Medicine (CAM). However, species adulteration in traded medicinal plant raw drugs threatens the reliability and safety of the CAM. Since morphological features of the medicinal plants are often not intact in the raw drugs, DNA barcoding was employed for species identification. Adulteration in 112 traded raw drugs was tested after creating a reference DNA barcode library consisting of 1,452 $\mathrm{rbcL}$ and $\mathrm{mat} K$ barcodes from 521 medicinal plant species. Species resolution of this library was $74.4 \%, 90.2 \%$, and $93.0 \%$ for $r b c L$, matK and $r b c L+m a t K$, respectively. DNA barcoding revealed adulteration in about $20 \%$ of the raw drugs, and at least $6 \%$ of them were derived from plants with completely different medicinal or toxic properties. Raw drugs in the form of dried roots, powders and whole plants were found to be more prone to adulteration than rhizomes, fruits, and seeds. Morphological resemblance, co-occurrence, mislabeling, confusing vernacular names, and unauthorized or fraudulent substitutions might have contributed to species adulteration in the raw drugs. Therefore, this library can be routinely used to authenticate traded raw drugs for the benefit of all stakeholders; traders, consumers, and regulatory agencies.
\end{abstract}


Keywords: Medicinal plants; Species adulteration; Raw drug trade; DNA barcoding; Complementary and alternative medicine.

Abbreviations: $r b c L$, ribulose-bisphosphate carboxylase; mat $K$, maturase $\mathrm{K}$; CTAB, cetyl trimethyl ammonium bromide; EDTA, ethylene diamine tetra acetic acid; PCR, polymerase chain reaction; NCBI, national center for biotechnology information; BOLD, barcode of life data systems; CAM, complementary and alternative medicine; IUCN, international union for conservation of nature; ENVIS, environmental information system.

\section{Introduction}

Complementary and alternative medicine (CAM) is widely used in developing countries where it contributes up to $80 \%$ of the healthcare needs of the people. It is also becoming more popular in developed countries due to the side effects and high cost of allopathic drugs. World Health Organization has reported that about 38 to $75 \%$ of the people in Australia, Belgium, Canada, France, and the USA have used CAM at least once in their lifetime (WHO 2002). Increasing global demand for CAM is expected to boost the medicinal plant raw drug trade from approximately 120 billion USD to 7 trillion USD by the year 2050 (Marichamy et al. 2014). Yet, frequent reports on species adulteration in traded raw drugs are major threat to the efficacy and safety of CAM (Stoeckle et al. 2011; Revathy et al. 2012; Ouarghidi et al. 2013; Seethapathy et al. 2014; Mishra et al. 2015), which could ultimately affect the trade industry. Therefore, identification of species adulteration in traded raw drugs becomes essential to consumers as well as traders.

Species authentication is a challenging task as most of the raw drugs are traded in the form of dried, fragmented or powdered leaves, flowers, seeds, stem bark, roots, and other plant parts, which do not possess intact diagnostic characters required for morphological 
identification by Linnaean taxonomy. Alternative methods such as chemotaxonomy, chromatography, and microscopy, which were adopted for this purpose showed only limited success in species identification. Major limitations of these methods includes involvement of complex chemistries, lack of unique compounds, influence of environmental factors, plant's age, and geographical variations (Techen et al. 2014). All these challenges can be largely overcome by using DNA barcoding, which does not rely on the morphology of plants, and therefore, is not affected by the above mentioned factors. Moreover, DNA barcoding can be done using live or dead tissue from any part of the plant at any stage of its life cycle. In fact, identification of species adulteration in traded raw drugs is one of the most useful applications of plant DNA barcoding. Though several chloroplast markers have been used for DNA barcoding of plants (Sucher and Carles 2008; Techen et al. 2014) the Consortium for the Barcode of Life Plant Working Group has recommended $r b c L$ and $m a t K$ as core DNA barcode markers for plants (CBOL Plant Working Group 2009).

The power of DNA barcoding to identify species has been demonstrated in several studies. Bruni et al. (2010) have demonstrated that DNA barcoding can be used for rapid and accurate identification of poisonous plant materials. Mattia et al. (2011) have employed a DNA barcoding approach for species identification in processed plant materials of commercial kitchen spices. Cornara et al. (2013) have successfully used DNA barcoding in a multidisciplinary approach for the identification of ingredients in commercial plant mixtures. However, there are only a few DNA barcoding studies in which a large number of medicinal plant raw drugs and natural health products were tested for species adulteration (Kool et al. 2012; Wallace et al. 2012; Newmaster et al. 2013). Such studies are very limited in India, which is endowed with about 7,500 recognized medicinal plants in various codified and noncodified systems of Indian medicine (Ved and Goraya 2008). The current study, reports a large scale study on species adulteration in diverse traded medicinal plant raw drugs. A 
medicinal plant reference DNA barcode library was assembled for 521 medicinal plants using $r b c L$ and $m a t K$ markers, and subsequently used to identify species adulteration in 112 traded raw drugs collected from the markets.

\section{Material and methods}

\section{Reference DNA barcode library}

Plants for this study were selected from the medicinal plant list provided by National Medicinal Plants Board (NMPB), Government of India, available at http://nmpb.nic.in/. Leaf samples were collected from different localities in India, which includes botanical gardens, herbal gardens, cultivated, and natural fields. Collected samples were identified by plant taxonomists and their corresponding vouchers were deposited at the SRM University herbarium (SRMUH). DNA barcodes were generated for 400 medicinal plant species, and combined with DNA barcodes of 121 species from our previous studies (Purushothaman et al. 2014; Nithaniyal et al. 2014; Vassou et al. 2015) to create a larger reference DNA barcode library for medicinal plant species.

\section{Collection of raw drug samples}

Medicinal plant raw drugs are traded across India through various outlets such as wholesale markets, food stores, and pharmacies. We collected single plant raw drugs that contained only one ingredient as per the label. Vernacular names for the raw drugs were obtained from traded-medicinal plants database (http://envis.frlht.org/botanical_search.php) using botanical name search. Vernacular names in Tamil were used to collect the plant raw drugs from markets. Specifically, we collected 112 raw drug samples from eight markets in Tamil Nadu, India (Fig. 1, Table S1) of which 68 plant raw drugs were in the form of dried plant parts such as leaves, carved roots, seeds, rhizomes, fruits, and whole plants, and the remaining 44 were in the form of powders of known (leaf, bark, seed, fruit, and whole plant) or unknown origin. All voucher samples of raw drugs were deposited in the SRM University 
herbarium. Details of the plant raw drugs collected are provided in Table S1. (supplementary data, Table S1.).

\section{Genomic DNA Isolation, PCR Amplification and DNA Sequencing}

Total genomic DNA was isolated by following the protocol of Saghai-Maroof et al. with minor modifications (Saghai-Maroof et al. 1984). About $100 \mathrm{mg}$ of sample was taken and ground using mortar and pestle by adding $500 \mu \mathrm{l}$ of CTAB buffer (100 mM Tris-HCl, 1.4 $\mathrm{M} \mathrm{NaCl}, 20 \mathrm{mM}$ EDTA, 2\% $\mathrm{CTAB}, \quad 1 \%$ beta-mercaptoethanol, and 2\% polyvinylpyrrolidone). Homogenized samples were transferred to $1.5 \mathrm{ml}$ centrifuge tubes, incubated in water bath at $60^{\circ} \mathrm{C}$ for 30 minutes. Samples were then extracted with equal volume of chloroform and centrifuged at $10,000 \mathrm{rpm}$ for 10 minutes. The aqueous phase was transferred to $1.5 \mathrm{ml}$ centrifuge tubes, precipitated by adding equal volume of ice-cold isopropanol, and centrifuged at 10,000 rpm for 10 minutes. The DNA pellet was washed twice with $70 \%$ ethanol, air-dried at room temperature, and dissolved in $100 \mu 1$ TE buffer.

Genomic DNA suitable for PCR amplification was successfully isolated from all samples. Universal primer pairs were used for PCR amplification of $r b c L$ ( $r b c L a-\mathrm{F}$ and rbcLajf634-R) (Levin et al. 2003; Fazekas et al. 2008) and matK (matK-1RKIM-F and matK3FKIM-R, Ki-Joong Kim, School of Life Sciences and Biotechnology, Korea University, Seoul, unpublished). PCR reaction mixture contained $1 \mathrm{X}$ buffer with $1.5 \mathrm{mM} \mathrm{MgCl} 2,0.2 \mu \mathrm{M}$ dNTPs, 5 pmol primers, and 1 unit Taq DNA polymerase. PCR amplification was done in a thermal cycler (Eppendorf, Germany) using the following protocol: Initial denaturation at $95^{\circ} \mathrm{C}$ for 5 minutes, 30 cycles of denaturation at $95^{\circ} \mathrm{C}$ for 30 seconds, annealing at $55^{\circ} \mathrm{C}$ for 30 seconds, and extension at $72^{\circ} \mathrm{C}$ for 1 minute, final extension at $72^{\circ} \mathrm{C}$ for 5 minutes, and hold at $16^{\circ} \mathrm{C}$. The PCR amplified products were purified using EZ-10 Spin Column PCR Purification Kit (Bio Basic Inc. Ontario, Canada). Sequencing of the PCR products was performed using Big-dye terminator chemistry in 3130xl Genetic Analyzer (Life 
Technologies, California, USA) by following the standard protocol as recommended by the manufacturer.

\section{Data analyses and identification of traded raw drugs}

Sequence quality was analyzed with Sequence Scanner Software v1.0 (Applied Biosystems, CA, USA) and full-length sequences were assembled using Codon Code Aligner, version 4.2.4 (CodonCode Corporation, MA, USA). Identification of traded raw drugs was done by comparing DNA barcodes obtained from the raw drug with the medicinal plant reference DNA barcode library. Species identification of the raw drugs was performed by best match method using TaxonDNA/Species identifier version 1.6.2 (Meier et al. 2006). This method assigns a query sequence to its closest match based on the genetic divergence. Genetic divergence was calculated as the percentage of mismatched nucleotides over the total number of aligned nucleotides. Unmatched samples were searched against the non-redundant nucleotide database of NCBI (http://blast.ncbi.nlm.nih.gov/Blast.cgi) and the Barcode of Life Data Systems (BOLD; www.boldsystems.org; Ratnasingham and Hebert 2007) using BLAST algorithm.

\section{Results}

\section{Assembly of reference DNA barcode library}

We generated a reference DNA barcode library consisting of 1,452 barcodes from 521 medicinal plant species $(1.64 \pm 1.01$ and $1.13 \pm 1.24$ barcodes per species for $r b c L$ and $m a t K$, respectively), which was subsequently used for the purpose of identifying species adulteration in the medicinal plant raw drugs that were collected from the markets. The 521 medicinal plant species were taxonomically diverse representing 374 genera, 119 families and 44 orders. DNA isolation was successful for all the samples and purity of the genomic DNA was sufficient for the purpose of DNA barcoding as indicated by $100 \%$ PCR and sequencing success with $r b c L$ marker. However, PCR and sequencing success rate was only 
$60 \%$ for $m a t K$ marker. Bidirectional sequencing yielded $94 \%$ full-length sequences for $r b c L$ (607bp). In the case of $m a t K$, full-length sequences were obtained from $47 \%$ of the samples, and the size varied between $828 \mathrm{bp}$ and $858 \mathrm{bp}$. Currently, the reference DNA barcode library contains 1,452 DNA barcodes from $r b c L$ and matK markers. The size of the barcodes varies from $504 \mathrm{bp}$ to $607 \mathrm{bp}$ and $624 \mathrm{bp}$ to $858 \mathrm{bp}$ for $r b c L$ and $m a t K$, respectively. All the DNA barcode data were submitted to BOLD under the accessions numbers SRM000170A to SRM000296A and SRM000670A to SRM000943C.

\section{Species resolution of reference DNA barcode library}

We calculated pairwise genetic divergence between species to evaluate the ability of $r b c L$ and $m a t K$ markers to differentiate medicinal plant species in the reference DNA barcode library. The $r b c L$ marker differentiated 388 out of 521 species $(74.4 \%)$ with the pairwise genetic divergence ranging between $0.2 \%$ and $19.0 \%$. The matK marker differentiated 287 out of 318 species $(90.2 \%)$ with the pairwise genetic divergence ranging between 0.2 and $21.0 \%$. When these two markers were combined, 296 out of 318 species $(93.0 \%)$ could be differentiated. However, in the tiered approach wherein the $r b c L$ sequence acts as scaffold on which the $m a t K$ sequence is placed for species differentiation, 450 out of 521 species $(86.3 \%)$ were differentiated.

\section{DNA barcoding of the traded raw drugs}

Genomic DNA was successfully isolated from all 112 raw drug samples using a standard protocol. PCR amplification and sequencing of $r b c L$ DNA barcodes were successful for all samples and chromatogram of the $r b c L$ DNA barcodes did not show mixed peaks in any of the raw drug sample analyzed. Therefore, the recovered barcodes could be directly compared with those present in the reference DNA barcode library for species identification. The DNA barcodes from 90 traded raw drugs (approx. 80\%) showed the highest identity with expected species in the medicinal plant reference DNA barcode library. However, ten of them 
also showed the highest identity with other species in the same genus or closely related genus in the same family.

\section{Identification of the species adulteration in traded raw drugs}

DNA barcodes from the remaining 22 raw drugs (approx. 20\%) showed 1.5 to $10.2 \%$ genetic divergence with expected species in the medicinal plant reference DNA barcode library, which strongly indicated species adulteration. DNA barcodes were searched against the non-redundant nucleotide database of NCBI and BOLD to establish their species identity. The DNA barcodes from 15 raw drugs showed 100\% identity with single species, and that from seven species showed $100 \%$ identity with multiple species from the same genus or different genera of the same family. Therefore, botanical identity could be established at species, genus, and family level for 15, 4, and 3 adulterated plants, respectively (Table 1). All 22 adulterant species belonged to different genera when compared with the species mentioned on the label, and 14 of them even belonged to a different family. The majority of traded raw drugs were in the form of powders, seeds, roots, and whole plants, and among them, adulteration was found to be the least within seeds (4.0\%). Adulteration with roots, whole plants, and powders was $42.9 \%, 33.3 \%$, and $22.7 \%$, respectively. We then compared medicinal properties of the expected species and the adulterant species for the 15 raw drugs in which the adulterated plant materials were identified to species level. Eight adulterant species shared some but not all the medicinal properties of the expected species. The remaining seven adulterant species had no resemblance with the expected species in terms of the medicinal values, and some of them were even reported to be toxic (supplementary data, Table S2.).

\section{Discussion}


Species adulteration, presence of one species in place of the other, in traded medicinal plant raw drugs is a growing concern in the context of increasing popularity and demand for CAM throughout the World (WHO 2004). Different terminologies such as adulteration, substitution, fraudulent substitution, admixture, mislabeling, contamination, filler, etc., are used to refer to species adulteration in raw drugs (Srirama et al. 2010; Wallace et al. 2012; Newmaster et al. 2013; Swetha et al. 2014; Kumar et al. 2015). In the present study, a traded medicinal plant raw drug sample was considered to have species adulteration if DNA barcoding did not identify the species that was mentioned on the label, and the actual species found was referred to as an adulterant species. Analysis of 112 traded medicinal plant raw drugs revealed the presence of adulterant species in about $20 \%$ of the samples. Adulteration was frequent in dried roots, powders, and whole plants, which are more difficult to identify based on morphology. All adulterations were presumably in the form of complete replacement of one species for the other as indicated by the absence of characteristic mixed peaks. Interestingly, all adulterant species were from a different genus, and in some cases, even from a different family. Taxonomic analysis of controversial drug plants (Nair 2004) that are often found as adulterant species show that $78 \%$ of them belong to other genera and families. The conserved $r b c L$ marker, which is capable of mostly genus level taxonomic discrimination but credited with good PCR amplification and sequencing success (Bafeel et al. 2012; Parmentier et al. 2013; Chen et al. 2014) would be sufficient to establish species adulteration in most of the traded raw drugs. However, ITS2 is evolving as a successful core or supplementary marker to increase species resolution and raw drug authentication (Newmaster et al. 2013; Seethapathy et al. 2014).

The efficiency of identifying species adulteration by DNA barcoding primarily depends on the taxonomic coverage of the reference DNA barcode library. Our reference DNA barcode library of 521 medicinal plant species contains authentic drug plants, closely related 
species, and their possible adulterants. The library covers 347 actively traded medicinal plants including 115 species of high trade value ( $>100$ metric tonnes per year) (Ved and Goraya 2008) and 42 controversial drug plants, which are frequently adulterated with nonauthentic species (Nair 2004). Therefore, this reference DNA barcode library could be utilized by the regulatory authorities to monitor the indiscriminate collection of medicinal plants from wild source, which becomes a major threat to biodiversity and sustainable utilization. Medicinally useful but threatened plants may be traded under the label of other plants to evade legal action. The reference DNA barcode library currently comprises 31 threatened plant species (IUCN, http://www.iucnredlist.org; ENVIS, http://envis.frlht.org/junclist.php) and can provide scientific evidence for species identity to support legal action against fraudulent or illicit trade.

The species adulterations found in the present study may be due to mislabeling, morphological resemblance, co-occurrence, confusion in vernacular names, substitution of one species for another as result of non-availability or high cost of the authentic species, etc. For example, initially we recovered Eclipta prostrata (L.) L. in place of Mukia maderaspatana (L.) M. Roem. However, DNA barcoding of seven more samples from the same market recovered M. maderaspatana in all the cases, which indicated the possibility of accidental mislabeling during packaging. Adulteration of Zaleya pentandra (L.) C. Jeffrey with Boerhavia diffusa L. may be due to their morphological resemblance (Suthari et al. 2011), and adulteration of Tephrosia purpurea (L.) Pers. with Sida cordifolia L. may be because they co-occur as weeds along the roadsides and barren lands. We recovered Aerva lanata (L.) Juss. and Andrographis paniculata (Burm.f.) Nees from the raw drugs labeled as Bergenia ciliata (Haw.) Sternb. and Swertia chirata Buch.-Ham. ex Wall., respectively. This may be because "Sirupilai" is the vernacular name for both A. lanata and B. ciliata and "Nilavembu" is the vernacular name for both $S$. chirata and A. paniculata. Bergenia ciliata 
and $S$. chirata are highly traded raw drugs but are distributed only in the Himalayan regions of India (Rai et al. 2000). Their non-availability in other regions might have encouraged substitution due to identical vernacular names. We recovered Abrus precatorius L. in place of Adenanthera pavonina L. which have very similar vernacular names, Kundumani and Anai Kundumani, respectively. This is also true for Azadirachta indica A. Juss. and Toona ciliata M. Roem. with vernacular names, Vembu, and Santhana Vembu, respectively. Species adulteration due to confusion in vernacular names was also reported in traded raw drugs of $S$. cordifolia (Vassou et al. 2015).

When adulterant species in raw drugs are used directly or in formulations, it is unlikely that the consumer will derive the same health benefits as expected from authentic species. In some cases, adulterant species is also claimed to possess the same medicinal properties as that of the authentic species. If so, fair practice would be to mention the correct name of that species on the label so that the consumer or the practitioner of the alternative medicine can take informed decision on using a particular raw drug. Alarmingly, some of the adulterant species are known to contain compounds that are toxic if consumed. For example, $Z$. pentandra was found in place of $B$. diffusa, which was reported to cause abortion (Quattrocchi 2012). Similarly, A. pavonina was found in place of A. precatorius which is known for the presence of toxins such as abrin and isolectins. Abrin is a toxin with the potential to pose a severe threat to both human and animal health, and its possession is regulated by law in several countries including the USA (www.selectagents.gov/Select Agents and Toxins List). The raw drugs from Albizia lebbeck(L.) Benth., Flacourtia indica (Burm.f.) Merr., and Gmelina asiatica L. were found to be replaced with species of Senna, which is reported to also have several species with toxic compounds (Nelson et al. 2007; Vashishtha et al. 2009; Quattrocchi 2012). 
Sale of raw drugs and herbal medicines as supplements remains largely unregulated in most countries. Trading of adulterant species with unrelated medicinal properties or toxic properties not only questions the ethical practices followed in the trade but also undermines the credibility and safety of CAM, which will ultimately affect the trade industry itself. Therefore, ensuring that only authentic plant materials are traded in the markets is important for both the consumers as well as the traders. The corrective measures to prevent species adulteration in raw drugs would include i) prohibiting the use of multiple vernacular names for single species or making it mandatory to provide botanical name along with vernacular name(s) on the label, ii) including DNA barcoding as a routine quality control measure, and iii) authentication of marketed plant materials using DNA barcoding by an independent agency.

\section{Acknowledgements}

We acknowledge Dr. K. Ravikumar (I-AIM, Bangalore, India), Dr. Subhash Rana (ISM Herbal Garden, Himachal Pradesh, India), Dr. Gurav Arun Manohar (NRIBAS, Pune, India) and Mr. K. Devanathan (Madras Christian College, Tamil Nadu) for their help in the taxonomic identification and collection of plants. We acknowledge the funding from SRM University, India.

\section{Author Contributions Statement}

P.M. and S.N. conceived and designed the research. S.N., S.L.V., P.S. and B.R. performed the experiments. P.M. and S.N. analyzed the data and wrote the manuscript. All authors reviewed and approved the final manuscript.

Conflict of interest: The authors declare that there is no conflict of interest associated with this publication. 


\section{References}

Bafeel, S.O., Arif, I.A., Bakir, M.A., Al Homaidan, A.A., Al Farhan, A.H., and Khan, H.A. 2012. DNA barcoding of arid wild plants using $r b c L$ gene sequences. Genet. Mol. Res.11: 1934-1941. doi: 10.4238/2012.July.19.12.

Bruni, I., De Mattia, F., Galimberti, A., Galasso, G., Banfi, E., Casiraghi, M., and Labra, M. 2010. Identification of poisonous plants by DNA barcoding approach. Int. J. Legal. Med. doi 10.1007/s00414-010-0447-3.

CBOL Plant Working Group. 2009. A DNA barcode for land plants. Proc. Natl. Acad. Sci. 106: 12794-12797. doi: 10.1073/pnas.0905845106.

Chen, J., Zhao, J., Erickson, D.L., Xia, N., and Kress, W.J. 2014. Testing DNA barcodes in closely related species of Curcuma (Zingiberaceae) from Myanmar and China. Mol. Ecol. Resour. doi: 10.1111/1755-0998.12319.

Cornara, L., Borghesi, B., Canali, C., Andrenacci, M., Basso, M., Federici, S., and Labra, M. 2013. Smart drugs: green shuttle or real drug? Int. J. Legal Med. 127: 1109-1123.

De Mattia, F., Bruni, I., Galimberti, A., Cattaneo, F., Casiraghi, M., and Labra, M. A comparative study of different DNA barcoding markers for the identification of some members of Lamiacaea. Food Res. Int. 44: 693-702.

ENVIS centre on medicinal plants, Ministry of Environment and Forest (MoEF), Government of India. FRLHT, Bangalore, http://envis.frlht.org/junclist.php. (Accessed: 14th August 2015).

Fazekas, A.J., Burgess, K.S., Kesanakurti, P.R., and Graham, S.W. 2008. Multiple multilocus DNA barcodes from the plastid genome discriminate plant species equally well. PLoS ONE3, e2802. doi:10.1371/journal.pone.0002802.

IUCN Red List Categories, IUCN Species Survival Commission, The World Conservation Union: http://www.iucnredlist.org. (Accessed: 14th August 2015). 
Kimura, M.1980. A simple method for estimating evolutionary rates of base substitutions through comparative studies of nucleotide sequences. J. Mol. Evol. 16: 111-20. PMID: 7463489.

Kool, A., de Boer, H.J., Kruger, A., Rydberg, A., Abbad, A., Bjork, L., and Martin G. 2012. Molecular identification of commercialized medicinal plants in Southern Morocco. PLoS ONE 6, e39459. doi:10.1371/journal.pone.0039459.

Levin, R.A., Wagner, W.L., Hoch, P.C., and Nepokroeff, M. 2003. Family-level relationships of Onagraceae based on chloroplast $r b c L$ and $n d h F$ data. Am. J. Bot. 90: 107-115. PMID: 21659085.

Kumar, J.U.S., Krishna, V., Seethapathy, G.S., Senthilkumar, U., Ragupathy, S., Ganeshaiah, K.N., Ganesan, R., Newmaster, S.G., Ravikanth, G., and Shaanker, R.U. 2015. DNA barcoding to assess species adulteration in raw drug trade of "Bala" (genus: Sida L.) herbal products in South India. Biochem. Syst. Ecol. 61: 501e509.

Marichamy, K., Kumar, N.Y. and Ganesan, A. 2014. Sustainable development in exports of herbals and Ayurveda, Siddha, Unani and Homeopathy (Ayush) in India. Sci. Park Res. J. 1, doi: 10.9780/23218045/1202013/49.

Meier, R., Shiyang, K., Vaidya, G., and Peter, K.L.N. 2006. DNA Barcoding and taxonomy in Diptera: a tale of high intraspecific variability and low identification success. Syst. Biol. 55: 715-728. PMID: 17060194.

Mishra, P., Kumar, A., Nagireddy, A., Mani, D.N., Shukla, A.K., Tiwari, R. and Sundaresan V. 2015. DNA barcoding: an efficient tool to overcome authentication challenges in the herbal market. Plant Biotechnol. J. doi: 10.1111/pbi.12419.

Nair, R.V. 2004. Controversial drug plants. Bio Briefs Series. Universities Press India Private Limited. 
National Medicinal Plants Board (NMPB), Government of India, New Delhi. Available at: http://www.nmpb.nic.in.

Nelson, L.S., Shih, R.D., and Balick, M. J. 2007. Handbook of Poisonous and Injurious Plants, $2^{\text {nd }}$ Edition, New York: Springer, 57-58.

Newmaster, S.G., Meghan, G., Dhivya, S., Sathiskumar, R., and Ragupathy, S. 2013. DNA barcoding detects contamination and substitution in North American herbal products. BMC Medicine. 11, 222. doi:10.1186/1741-7015-11-222.

Nithaniyal, S., Newmaster, S.G., Ragupathy, S., Krishnamoorthy, D., Vassou, S.L., and Parani, M. 2014. DNA barcode authentication of wood samples of threatened and commercial timber trees within the Tropical Dry Evergreen Forest of India. PLoS ONE9, e107669. doi:10.1371/journal.pone.0107669.

Ouarghidi, A., Martin, G.J., Powell, B., Esser, G., and Abbad, A., 2013. Botanical identification of medicinal roots collected and traded in Morocco and comparison to the existing literature, J. Ethnobiol. Ethnomed, 9:59. doi:10.1186/1746-4269-9-59.

Parmentier, I. Duminil, J., Kuzmina, M., Philippe, M., Thomas, D.W., Kenfack, D., Chuyong, G.B., Cruaud, C., and Hardy, O.J. 2013. How effective are DNA barcodes in the identification of African rainforest trees? PLoS ONE8, e54921. doi: 10.1371/journal.pone.0054921.

Purushothaman, N., Newmaster, S.G., Ragupathy, S., Stalin, N., Suresh, D., Arunraj, D.R., Gnanasekaran, G., Vassou, S.L., Narasimhan, D., and Parani, M. 2014. A tiered barcode authentication tool to differentiate medicinal Cassia species in India. Genet. Mol. Res.13: 2959-2968. doi: 10.4238/2014.April.16.4.

Ratnasingham, S., and Hebert, P.D.N. 2007. BOLD: The Barcode of Life Data System (www.barcodinglife.org). Mol Ecol Notes 7(3): 355-364 doi: 10.1111/j.14718286.2007.01678.x 
Quattrocchi, U. 2012. CRC World Dictionary of Medicinal and Poisonous Plants: Common Names.

Rai, L. K., Prasad, P., and Sharma, E. 2000. Conservation threats to some important medicinal plants of the Sikkim Himalaya. Biol. Conserv. 93: 27-33. doi:10.1016/S00063207(99)00116-0.

Revathy, S.S., Rathinamala, R., and Murugesan, M. 2012. Authentication methods for drugs used in Ayurveda, Siddha And Unani Systems of medicine: An overview. IJPSR. 3: $2352-2361$.

Saghai-Maroof, M.A., Soliman, K.M., Jorgensen, R.A., and Allard, R.W. 1984. Ribosomal DNA spacer-length polymorphism in barley: Mendelian inheritance, chromosomal location, and Population dynamics. Proc. Natl. Acad. Sci. 81: 8014-8019. PMID: 6096873.

Saitou, N., and Nei, M. 1987. The neighbor-joining method: A new method for reconstructing phylogenetic trees. Mol. Biol. Evol. 4: 406-425. PMID: 3447015.

Seethapathy, G.S., Ganesh, D., Kumar, J.U.S., Senthilkumar, U., Newmaster, S.G., Ragupathy, S., Shaanker, R.U., and Ravikanth, G. 2014. Assessing product adulteration in natural health products for laxative yielding plants, Cassia, Senna, and Chamaecrista, in Southern India using DNA barcoding. Int. J. Legal. Med. 1-8. doi: 10.1007/s00414-0141120-z.

Srirama, R. Senthilkumar, U., Sreejayan, N., Ravikanth, G., Gurumurthy, B.R., Shivanna, M.B., Sanjappa, M., Ganeshaiah, K.N., and Shaanker, R.U. 2010. Assessing species admixtures in raw drug of Phyllanthus, a hepato-protective plant using molecular tools. J. Ethnopharmacol.130: 208-215. doi:10.1016/j.jep.2010.04.042. 
Stoeckle, M.Y., Gamble, C.C., Kirpekar, R., Young, G., Ahmed, S., and Little, D.P. 2011. Commercial teas highlight plant DNA barcode identification successes and obstacles. Sci. Rep. 1, 1-7.

Sucher, N.J., and Carles, M.C. 2008. Genome-based approaches to the authentication of medicinal plants. Planta. Med. 74: 603-623. doi: 10.1055/s-2008-1074517.

Suthari, S., Kota, S., Kumar, V.A., Kumar, P.N., Sadanandam, A., and Raju, V.S. 2011. 'Galijeru' as the Ayurvedic drug Vrshabhu : Assessing Admixture Problem and Proper Identification. J. Theor. Exp. Biol. 7: 127-134.

Swetha, V.P., Parvathy, V.A., Sheeja T.E., and Sasikumar, B. 2014. DNA Barcoding for Discriminating the Economically Important Cinnamomum verum from Its Adulterants, Food Biotechnology. 28: 183-194, doi: 10.1080/08905436.2014.931239.

Tamura, K., Peterson, D., Peterson, N., Stecher, G., Nei, M., and Kumar, S. 2011. MEGA5: Molecular evolutionary genetics analysis using maximum likelihood, evolutionary distance, and maximum parsimony methods. Mol. Biol. Evol. 28: 2731-9. PMID: 21546353

Techen, N., Parveen, I., Pan, Z., and Khan, I.A. 2014. DNA barcoding of medicinal plant material for identification. Curr. Opin. Biotech. 25: 103-110. doi:10.1016/j.copbio.2013.09.010.

Vashishtha, V.M., John, T.J., and Kumar, A. 2009. Clinical \& pathological features of acute toxicity due to Cassia occidentalis in vertebrates. Indian. J. Med. Res. 130: 23-30. PMID: 19700797.

Vassou, S.L., Kusuma, G., and Parani, M. 2015. DNA barcoding for species identification from dried and powdered plant parts: A case study with authentication of the raw drug market samples of Sida cordifolia. Gene. 559: 86-93. doi:10.1016/j.gene.2015.01.025. 
Ved, D.K., and Goraya, G.S. 2008. Demand and Supply of Medicinal Plants in India. FRLHT.

Wallace, L. J., Boilard, S.M.A.L., Eagle, S.H.C., Spall, J.L., Shokralla, S., and Hajibabaei, M. 2012. DNA barcodes for everyday life: routine authentication of natural health products. Food Res. Int. 49: 446-452. doi: 10.1016/j.foodres.2012.07.048.

Wohlmuth, H., Savage, K., Dowell, A., and Mouatt, P. 2014. Adulteration of Ginkgo biloba products and a simple method to improve its detection. Phytomedicine. 21: 912-918. doi: 10.1016/j.phymed.2014.01.010.

World Health Organization (WHO). 2002. Traditional Medicine Strategy 2002-2005, World Health Organization, Geneva. Avaliable at: http://www.wpro.who.int/health_technology/book_who_traditional_medicine_strategy_2 002_2005.pdf.

World Health Organization (WHO). 2004. WHO guidelines on safety monitoring of herbal medicines in pharmacovigilance systems, World Health Organization Geneva. Avaliable at: http://apps.who.int/medicinedocs/documents/s7148e/s7148e.pdf. 
Table 1. Details of the adulterant species found among the 112 traded medicinal plant raw drugs that were tested by DNA barcoding.

\begin{tabular}{|c|c|c|c|c|}
\hline $\begin{array}{l}\text { Sample } \\
\text { ID }\end{array}$ & Form & Expected plant species & $\begin{array}{l}\text { Species ID by DNA } \\
\text { barcoding }\end{array}$ & Family \\
\hline RD066 & Dried leaf & Adenanthera pavonina $\mathrm{L}$. & Abrus precatorius L. & Fabaceae \\
\hline RD044 & Powder & Albizia lebbeck (L.) Benth. & Senna sp. & Fabaceae \\
\hline RD026 & Dried root & $\begin{array}{l}\text { Anisomeles malabarica (L.) } \\
\text { R.Br. ex Sims }\end{array}$ & Araliaceae & Araliaceae \\
\hline RD067 & $\begin{array}{l}\text { Dried whole } \\
\text { plant }\end{array}$ & Barleria prionitis L. & $\begin{array}{l}\text { Andrographis paniculata } \\
\text { (Burm.f.) Nees }\end{array}$ & Acanthaceae \\
\hline RD068 & Powder & Bauhinia purpurea L. & Peltophorum sp. & Fabaceae \\
\hline RD140 & Powder & $\begin{array}{l}\text { Bergenia ciliata (Haw.) } \\
\text { Sternb. }\end{array}$ & $\begin{array}{l}\text { Aerva lanata (L.) Juss. } \\
\text { Zaleya pentandra (L.) }\end{array}$ & Amaranthaceae \\
\hline RD045 & Dried root & Boerhavia diffusa $\mathrm{L}$. & C.Jeffrey & Aizoaceae \\
\hline RD061 & Dried rhizome & Calamus rotang $\mathrm{L}$. & Araceae & Araceae \\
\hline RD193 & Powder & $\begin{array}{l}\text { Calotropis procera (Aiton) } \\
\text { Dryand. }\end{array}$ & $\begin{array}{l}\text { Enicostema axillare (Poir. } \\
\text { ex Lam.) A.Raynal }\end{array}$ & Gentianaceae \\
\hline RD084 & $\begin{array}{l}\text { Dried whole } \\
\text { plant }\end{array}$ & $\begin{array}{l}\text { Calycopteris floribunda } \\
\text { (Roxb.) Lam. ex Poir. } \\
\text { Catharanthus roseus (L.) }\end{array}$ & $\begin{array}{l}\text { Iphigenia indica (L.) } \\
\text { A.Gray ex Kunth }\end{array}$ & Colchicaceae \\
\hline RD071 & Powder & G.Don & $\begin{array}{l}\text { Ocimum tenuiflorum L. } \\
\text { Tephrosia purpurea (L.) }\end{array}$ & Lamiaceae \\
\hline RD004 & Dried root & Clitoria ternatea $\mathrm{L}$. & Pers. & Fabaceae \\
\hline RD073 & Dried root & $\begin{array}{l}\text { Cordia obliqua Willd. } \\
\text { Flacourtia indica (Burm.f.) }\end{array}$ & Azima tetracantha Lam. & Salvadoraceae \\
\hline RD074 & Powder & Merr. & Senna sp. & Fabaceae \\
\hline RD075 & Powder & Gmelina asiatica $\mathrm{L}$. & $\begin{array}{l}\text { Senna sp. } \\
\text { Andrographis paniculata }\end{array}$ & Fabaceae \\
\hline RD100 & Powder & $\begin{array}{l}\text { Melia azedarach } \mathrm{L} . \\
\text { Mukia maderaspatana (L.) }\end{array}$ & (Burm.f.) Nees & Acanthaceae \\
\hline RD011 & Powder & $\begin{array}{l}\text { M.Roem. } \\
\text { Polyalthia longifolia (Sonn.) }\end{array}$ & Eclipta prostrata (L.) L. & Asteraceae \\
\hline RD080 & Dried root & Thwaites & $\begin{array}{l}\text { Asclepidiaceae } \\
\text { Tephrosia purpurea (L.) }\end{array}$ & Asclepidiaceae \\
\hline RD054 & Dried root & Sida cordifolia $\mathrm{L}$. & Pers. & Fabaceae \\
\hline RD056 & $\begin{array}{l}\text { Dried whole } \\
\text { plant }\end{array}$ & $\begin{array}{l}\text { Swertia chirata Buch.-Ham. } \\
\text { ex Wall. } \\
\text { Teramnus labialis (L.f.) }\end{array}$ & $\begin{array}{l}\text { Andrographis paniculata } \\
\text { (Burm.f.) Nees } \\
\text { Vigna radiata (L.) }\end{array}$ & Acanthaceae \\
\hline RD188 & Dried seed & Spreng. & R.Wilczek & Fabaceae \\
\hline RD147 & Powder & Toona ciliata M.Roem. & Azadirachta indica A.Juss. & Meliaceae \\
\hline
\end{tabular}




\section{Figure legend}

Fig. 1 Different forms of the traded medicinal plant raw drugs that were used for present study. Flower buds: Michelia champaca (a). Rhizomes: Acorus calamus (b), Zingiber officinale (c). Tubers: Cyperus rotundus (d). Whole plants: Evolvulus alsinoides (e), Mollugo cerviana (f). Dried stems: Cissus quadrangularis (g), Tinospora cordifolia (h). Roots: Holarrhena antidysenterica (i), Hemidesmus indicus (j), Morinda pubescens (k), Ficus benghalensis (1). Seeds: Moringa oleifera (m), Cleome viscosa (n), Semecarpus anacardium (o), Strychnos nuxvomica (p), Mucuna pruriens (q), Eleusine coracana (r), Abrus precatorius (s), Papaver somniferum (t). Powders: Murraya koenigii (u), Erythrina variegate (v), Centella asiatica (w), Cardiospermum halicacabum (x).

\section{Supplementary data}

\section{Table legends}

Table S1. Details of the 112 traded medicinal plant raw drugs that were collected for the current study.

Table S2. Comparison of the medicinal properties of plants used in complementary and alternative medicine versus the adulterant species 

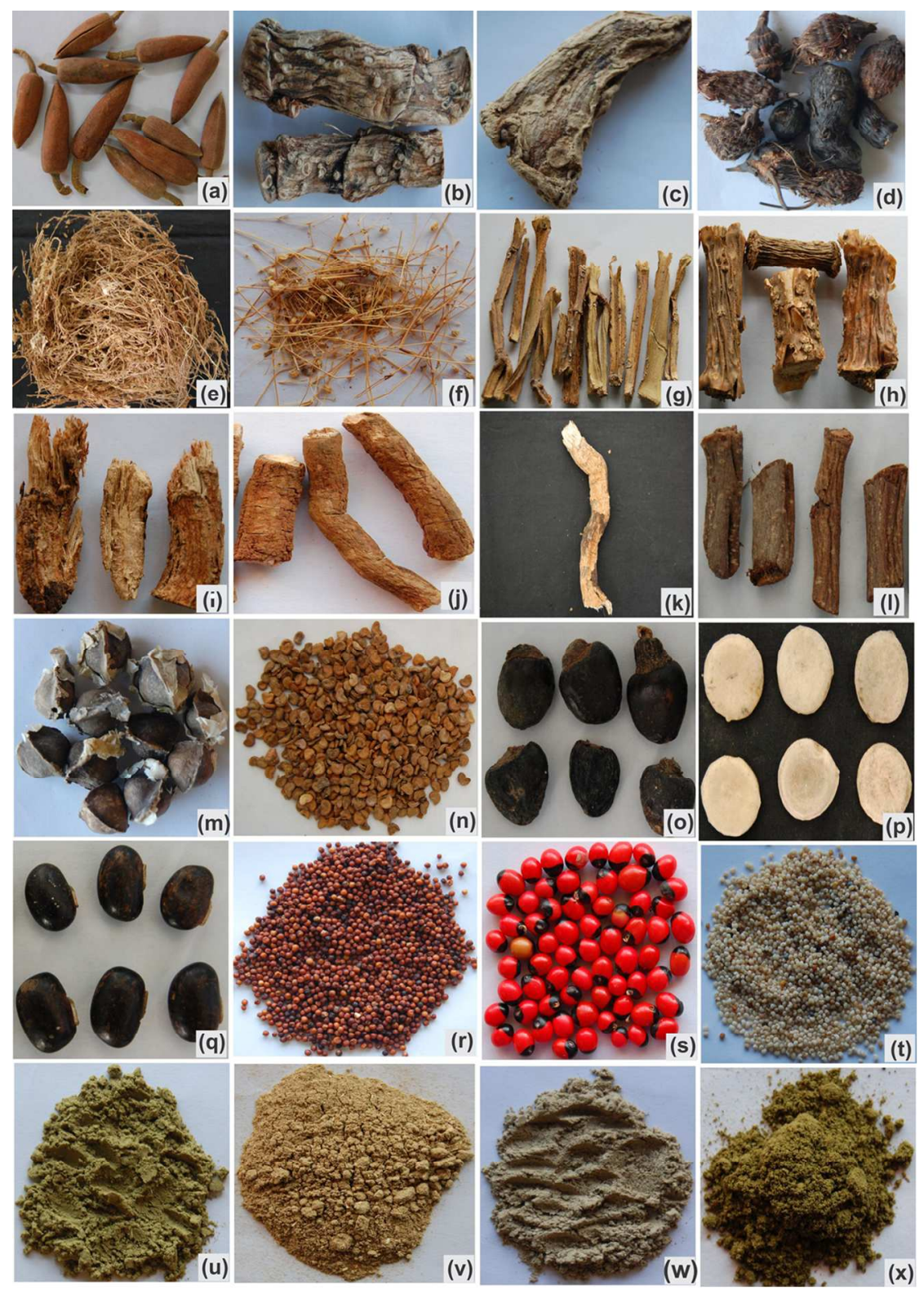

Fig. 1 Different forms of the traded medicinal plant raw drugs that were used for present study $101 \times 143 \mathrm{~mm}(300 \times 300$ DPI $)$ 
Identification of species adulteration in traded medicinal plant raw drugs using DNA barcoding

Stalin Nithaniyal, Sophie Lorraine Vassou, Poovitha Sundar, Balaji Raju, Parani Madasamy*

Department of Genetic Engineering, Center for DNA Barcoding, SRM University, Kattankulathur 603203, India.

*Corresponding author: Parani Madasamy 
Table S1. Details of the 112 traded medicinal plant raw drugs that were collected for the current study.

\begin{tabular}{|c|c|c|c|c|c|c|}
\hline $\begin{array}{l}\text { Sample } \\
\text { ID }\end{array}$ & $\begin{array}{l}\text { Place of } \\
\text { collection }\end{array}$ & $\begin{array}{l}\text { Form of the } \\
\text { sample }\end{array}$ & Botanical name & Family & $\begin{array}{l}\text { Vernacular } \\
\text { Name in Tamil }\end{array}$ & Trade name \\
\hline RD021 & Vellore & Dried seed & Abrus precatorius L. & Fabaceae & Kundumani & Gunja \\
\hline RD001 & Madurai & Leaf powder & Abutilon indicum (L.) Sweet & Malvaceae & Thuthi & Tutti \\
\hline RD023 & Theni & Dried rhizome & Acorus calamus L. & Acoraceae & Vasambu & Vach \\
\hline RD066 & Madurai & Dried leaf & Adenanthera pavonina L. & Fabaceae & Anai Kundumani & Kamboji \\
\hline RD044 & Trichy & Powder & Albizia lebbeck(L.) Benth. & Fabaceae & Vagai & Vaakaveru \\
\hline RD197 & Tanjore & Dried seed & Amaranthus tricolor L. & Amaranthaceae & Thandukkeerai & Alpamarisa \\
\hline RD161 & Virudhunagar & Dried seed & Anethum graveolens L. & Apiaceae & Sadakuppai & Sowa \\
\hline RD026 & Vellore & Dried root & $\begin{array}{l}\text { Anisomeles malabarica (L.) } \\
\text { R.Br. ex Sims }\end{array}$ & Lamiaceae & Peymiratti & Karimthumpa \\
\hline RD067 & Madurai & $\begin{array}{l}\text { Dried whole } \\
\text { plant }\end{array}$ & Barleria prionitis L. & Acanthaceae & Semmulli & Vajradanti \\
\hline RD068 & Madurai & Powder & Bauhinia purpurea L. & Fabaceae & Mandharai & Sonachal \\
\hline RD140 & Virudhunagar & Powder & Bergenia ciliata (Haw.) Sternb. & Saxifragaceae & Sirupilai & Pashnabheda \\
\hline RD045 & Trichy & Dried root & Boerhavia diffusa L. & Nyctaginaceae & Mukkarattai & Punarnava \\
\hline RD002 & Chennai & Dried seed & Brassica juncea (L.) Czern. & Brassicaceae & Kadugu & Sasuve Bili \\
\hline RD061 & Trichy & Dried rhizome & Calamus rotang $\mathrm{L}$. & Arecaceae & Pirapan kizhangu & Bet \\
\hline RD193 & Tanjore & Powder & $\begin{array}{l}\text { Calotropis procera (Aiton) } \\
\text { Dryand. }\end{array}$ & Fabaceae & Erukku & Akada Phool \\
\hline RD084 & Madurai & $\begin{array}{l}\text { Dried whole } \\
\text { plant }\end{array}$ & $\begin{array}{l}\text { Calycopteris floribunda (Roxb.) } \\
\text { Lam. ex Poir. }\end{array}$ & Combretaceae & Therulankodi & Pullaaniyila \\
\hline
\end{tabular}




\begin{tabular}{|c|c|c|c|c|c|c|}
\hline RD109 & Trichy & Powder & Cardiospermum halicacabum L. & Sapindaceae & Mudakkathan & Mudakkathan \\
\hline RD160 & Vellore & Dried seed & Carica papaya $\mathrm{L}$. & Caricaceae & Pappali & Papaya \\
\hline RD071 & Madurai & Powder & Catharanthus roseus (L.) G.Don & Apocynaceae & Nithyakalyani & Sadabahar \\
\hline RD003 & Theni & Leaf powder & Centella asiatica (L.) Urb. & Apiaceae & Vallarai & Brahmi booti \\
\hline RD047 & Trichy & Dried stem & Cissus quadrangularis L. & Vitaceae & Pirandai & Asthisamhrta \\
\hline RD030 & Vellore & Dried seed & Cleome viscosa L. & Cleomaceae & Naikkadugu & Naikadugu \\
\hline RD004 & Chennai & Dried root & Clitoria ternatea $\mathrm{L}$. & Fabaceae & Sankapushpam & Kajli \\
\hline RD073 & Madurai & Dried root & Cordia obliqua Willd. & Boraginaceae & $\begin{array}{l}\text { Mookuchalipazha } \\
\mathrm{m}\end{array}$ & Sapistan \\
\hline RD005 & Chennai & Seed powder & Coriandrum sativum L. & Apiaceae & Kothumalli & Dhaniya \\
\hline RD104 & Chennai & Flower powder & Crocus sativus L. & Iridaceae & Kungumappoo & Kesar \\
\hline RD149 & Vellore & Dried seed & Cuminum cyminum $\mathrm{L}$. & Apiaceae & Seeragam & Shahjeera \\
\hline RD195 & Chennai & Powder & Cynodon dactylon (L.) Pers. & Poaceae & Arugampul & Durva \\
\hline RD111 & Kancheepuram & Dried tuber & Cyperus rotundus L. & Poaceae & Korai kizanghu & Nagarmotha \\
\hline RD049 & Trichy & Dried seed & Datura metel L. & Solanaceae & Umathai & Duttura \\
\hline RD063 & Trichy & $\begin{array}{l}\text { Dried whole } \\
\text { plant }\end{array}$ & $\begin{array}{l}\text { Desmostachya bipinnata (L.) } \\
\text { Stapf }\end{array}$ & Poaceae & Darbhaipul & Dharbha \\
\hline RD050 & Trichy & Dried Tuber & Dioscorea bulbifera L. & Dioscoreaceae & Kattuvalli & Varahi kand \\
\hline RD131 & Kancheepuram & Leaf powder & Eclipta prostrata (L.) L. & Asteraceae & Karisalangani & Bhringaraj \\
\hline RD219 & Kancheepuram & Dried seed & Eleusine coracana (L.) Gaertn. & Poaceae & Kezhvaragu & Nachani \\
\hline RD031 & Theni & $\begin{array}{l}\text { Dried whole } \\
\text { plant }\end{array}$ & $\begin{array}{l}\text { Enicostema axillare (Poir. ex } \\
\text { Lam.) A.Raynal }\end{array}$ & Gentianaceae & Vellarugu & Mamejava \\
\hline RD006 & Chennai & Leaf powder & Erythrina variegata L. & Fabaceae & Kalyana murungai & Murikkila \\
\hline RD007 & Chennai & $\begin{array}{l}\text { Whole plant } \\
\text { powder }\end{array}$ & Euphorbia hirta L. & Euphorbiaceae & Amman-pacharisi & Dudhika \\
\hline RD051 & Trichy & $\begin{array}{l}\text { Dried whole } \\
\text { plant }\end{array}$ & Evolvulus alsinoides (L.) L. & Convolvulaceae & Vishnukranthi & Shankhpush \\
\hline RD064 & Trichy & Dried root & Ficus benghalensis L. & Moraceae & Aal & Vada chhal \\
\hline RD074 & Madurai & Powder & $\begin{array}{l}\text { Flacourtia indica (Burm.f.) } \\
\text { Merr. }\end{array}$ & Fabaceae & Sothaikala & Kattar \\
\hline RD210 & Chennai & Dried fruit & Foeniculum vulgare Mill. & Apiaceae & Sombu & Badiyan Khatal \\
\hline RD132 & Chennai & Dried root & Glycyrrhiza glabra L. & Fabaceae & Athimathuram & Mulethi \\
\hline
\end{tabular}




\begin{tabular}{|c|c|c|c|c|c|c|}
\hline RD075 & Madurai & Powder & Gmelina asiatica $\mathrm{L}$. & Lamiaceae & Nelakumizh & Kapas Beej \\
\hline RD182 & Kancheepuram & Dried seed & Gossypium herbaceum L. & Malvaceae & Paruthi & Kapas \\
\hline RD122 & Kancheepuram & Powder & $\begin{array}{l}\text { Gymnema sylvestre (Retz.) } \\
\text { R.Br. ex Sm. }\end{array}$ & Asclepiadaceae & Sirukurinjan & Gudmar \\
\hline RD097 & Virudhunagar & Dried fruit & Helicteres isora $\mathrm{L}$. & Malvaceae & Valamburi & Marodphali \\
\hline RD076 & Madurai & Powder & Heliotropium indicum L. & Scrophulariaceae & Thelkodukku & Thekkada \\
\hline RD098 & Virudhunagar & Dried root & $\begin{array}{l}\text { Hemidesmus indicus (L.) R. Br. } \\
\text { ex Schult. }\end{array}$ & Apocynaceae & Nannari & Anatmool \\
\hline RD032 & Theni & Leaf powder & Hibiscus rosa-sinensis L. & Malvaceae & Semparuthi & Jashwanti \\
\hline RD099 & Virudhunagar & Dried seed & Hibiscus sabdariffa L. & Malvaceae & Pulichai-keerai & Patwa \\
\hline RD105 & Chennai & Dried seed & Hippophae rhamnoides L. & Elaeagnaceae & Ameel & Sea Buckthorn \\
\hline RD144 & Kancheepuram & Dried root & $\begin{array}{l}\text { Holarrhena antidysenterica } \\
\text { (Roth) Wall. ex A.DC. }\end{array}$ & Apocynaceae & Veppalai & Kutja \\
\hline RD106 & Kancheepuram & $\begin{array}{l}\text { Whole plant } \\
\text { powder }\end{array}$ & $\begin{array}{l}\text { Hybanthus enneaspermus (L.) } \\
\text { F.Muell. }\end{array}$ & Violaceae & Orithazh thamarai & Ratanpurus \\
\hline RD123 & Kancheepuram & $\begin{array}{l}\text { Dried whole } \\
\text { plant }\end{array}$ & $\begin{array}{l}\text { Hygrophila auriculata } \\
\text { (Schumach.) Heine }\end{array}$ & Acanthaceae & Neermulli & Tal makhana \\
\hline RD087 & Madurai & Dried stem & $\begin{array}{l}\text { Ichnocarpus frutescens (L.) } \\
\text { W.T.Aiton }\end{array}$ & Apocynaceae & Udarkodi & Dudhi, Sariva \\
\hline RD008 & Theni & Leaf powder & Justicia adhatoda L. & Acanthaceae & Adathodai & Adusa \\
\hline RD009 & Chennai & Leaf powder & Lawsonia inermis L. & Lythraceae & Marudhani & Mehndi \\
\hline RD208 & Chennai & Dried seed & Luffa acutangula (L.) Roxb. & Cucurbitaceae & Peerku & Tori \\
\hline RD100 & Virudhunagar & Powder & Melia azedarach L. & Meliaceae & Malaivembu & Bakayan phal \\
\hline RD093 & Vellore & Flower & Mesua ferrea $\mathrm{L}$. & Calophyllaceae & Nagapoo & Nagkeshar \\
\hline RD033 & Vellore & Flower & Michelia champaca L. & Magnoliaceae & Shenbagam & Champaka \\
\hline RD010 & Chennai & Dried seed & Mirabilis jalapa $\mathrm{L}$. & Nyctaginaceae & Andhimandhaarai & Gulabash \\
\hline RD035 & Chennai & $\begin{array}{l}\text { Dried Whole } \\
\text { plant }\end{array}$ & Mollugo cerviana (L.) Ser. & Molluginaceae & Parpadagam & Parpata \\
\hline RD078 & Madurai & Dried root & Morinda pubescens $\mathrm{Sm}$. & Rubiaceae & Nuna & Manjanatthi \\
\hline RD034 & Chennai & Dried seed & Moringa oleifera Lam. & Moringaceae & Murungai & $\begin{array}{l}\text { Sahenjana } \\
\text { chaal }\end{array}$ \\
\hline RD052 & Trichy & Dried seed & Mucuna pruriens (L.) DC. & Fabaceae & Punaikkali & Kaunch beej \\
\hline RD011 & Theni & Leaf powder & Mukia maderaspatana (L.) & Cucurbitaceae & Musumusukkai & Mucukkai \\
\hline
\end{tabular}




\begin{tabular}{|c|c|c|c|c|c|c|}
\hline & & & M.Roem. & & & \\
\hline RD165 & Kancheepuram & Dried seed & Nigella sativa L. & Ranunculaceae & Karunseeragam & Kalongi \\
\hline RD101 & Virudhunagar & Powder & Oxalis corniculata $\mathrm{L}$. & Oxalidaceae & Puliiyarai & Puliyaarila \\
\hline RD201 & Tanjore & Dried seed & Papaver somniferum L. & Papaveraceae & Gasha-gasha & Khaskhas \\
\hline RD037 & Chennai & $\begin{array}{l}\text { Dried } \\
\text { inflorescence }\end{array}$ & Piper longum L. & Piperaceae & Thippili & Pippali \\
\hline RD013 & Chennai & Dried fruit & Piper nigrum L. & Piperaceae & Milagu & Kalimirch \\
\hline RD080 & Madurai & Dried root & $\begin{array}{l}\text { Polyalthia longifolia (Sonn.) } \\
\text { Thwaites }\end{array}$ & Annonaceae & Nettilingam & Ashok \\
\hline RD053 & Trichy & Dried seed & Semecarpus anacardium L.f. & Anacardiaceae & Serankottai & Balave \\
\hline RD028 & Theni & Dried Flower & Senna auriculata (L.) Roxb. & Fabaceae & Avaram & Avarai \\
\hline RD081 & Madurai & Powder & Senna tora (L.) Roxb. & Fabaceae & Senavu & Chakoda Beeja \\
\hline RD015 & Chennai & Dried seed & Sesamum indicum L. & Pedaliaceae & Ellu & Til \\
\hline RD054 & Trichy & Dried root & Sida cordifolia L. & Malvaceae & Kurunthotti & Bala \\
\hline RD017 & Theni & Leaf powder & Solanum trilobatum L. & Solanaceae & Thoodhuvalai & Alarka \\
\hline RD018 & Chennai & Fruit powder & $\begin{array}{l}\text { Solanum xanthocarpum Schrad. } \\
\text { \& H. Wendl. }\end{array}$ & Solanaceae & Kandanghathiri & Kateli \\
\hline RD055 & Trichy & Dried seed & Strychnos nux-vomica L. & Loganiaceae & Yetti-kottai & Kuchla \\
\hline RD056 & Trichy & $\begin{array}{l}\text { Dried whole } \\
\text { plant }\end{array}$ & $\begin{array}{l}\text { Swertia chirata Buch.-Ham. ex } \\
\text { Wall. }\end{array}$ & Gentianaceae & Nilavembu & Chiraiyata \\
\hline
\end{tabular}




\begin{tabular}{|c|c|c|c|c|c|c|}
\hline RD188 & Kancheepuram & Dried seed & Teramnus labialis (L.f.) Spreng. & Fabaceae & Kattu uluntu & Masparni \\
\hline RD039 & Theni & Dried fruit & $\begin{array}{l}\text { Terminalia arjuna (Roxb. ex } \\
\text { DC.) Wight \& Arn. }\end{array}$ & Combretaceae & Marudhu & Arjun \\
\hline RD041 & Theni & Dried fruit & Terminalia chebula Retz. & Combretaceae & Kadukkai & Harda \\
\hline RD147 & Kancheepuram & Powder & Toona ciliata M. Roem. & Meliaceae & Santhanavembu & $\begin{array}{l}\text { Thooniyanoika } \\
\mathrm{m}\end{array}$ \\
\hline RD103 & Virudhunagar & Dried root & Vetiveria zizanioides (L.) Nash & Poaceae & Vetiver & Lavancha \\
\hline RD107 & Kancheepuram & Dried seed & Vigna unguiculata (L.) Walp. & Fabaceae & Karamani & Alasunda \\
\hline RD065 & Trichy & Leaf powder & Vitex negundo L. & Verbenaceae & Karunochi & Neergundi \\
\hline RD211 & Tanjore & Powder & Withania somnifera (L.) Dunal & Solanaceae & Aswaganthi & Ashwagandha \\
\hline RD185 & Chennai & Dried rhizome & Zingiber officinale Roscoe & Zingiberaceae & Sukku & Sonth \\
\hline RD091 & Madurai & Powder & Ziziphus mauritiana Lam. & Rhamnaceae & Elandhai & Ber \\
\hline
\end{tabular}


Table S2. Comparison of the medicinal properties of plants used in complementary and alternative medicine versus the adulterant species

\begin{tabular}{lll}
\hline S.No & Expected Plants Name & Adulterant Plants Name \\
\hline 1. & $\begin{array}{l}\text { Adenanthera pavonina } \text { L. } \\
\text { Pulmonary Affection, Chronic } \\
\text { Ophthalmia, Chronic Rheumatism, Gout, } \\
\text { Haematuria, and Haematemesis. }\end{array}$ & $\begin{array}{l}\text { Abrus precatorius L. } \\
\text { Diuretic, Skin Diseases, Neurological } \\
\text { disorders, Purgative, Emetic, }\end{array}$ \\
Antiphlogistic, and Aphrodisiac. \\
2. & $\begin{array}{l}\text { Barleria prionitis } \text { L. } \\
\text { Toothache, Catarrhal Affections, Cough, } \\
\text { and Anasarca. }\end{array}$ & $\begin{array}{l}\text { Andrographis paniculata (Burm.f.) Nees } \\
\text { Anthelmintic, Diuretic, Lung Disorders, }\end{array}$ \\
& Febrifuge, and Diabetes.
\end{tabular}

3. Bergenia ciliata (Haw.) Sternb.

Aerva lanata (L.) Juss.

Demulcent, Astringent, Dysuria, Calculus, Laxative, Pulmonary Affection, throat Dysentery, Ulcers, Spleen enlargement, Cough, and Fever.

4. Boerhavia diffusa $\mathrm{L}$. Purgative, Anthelmintic, Febrifuge, Diuretic, Asthma, Anemia, and Oedema.

Zaleya pentandra (L.) C.Jeffrey

Abortifacient, Used in Scorpion-Sting.

5. Calotropis procera (Aiton) Dryand. Skin Diseases, Pruritus, Gulma, Ascites, Wound Healing, Respiratory Disorders, and Piles.

Enicostema axillare (Poir. ex Lam.)

A.Raynal Laxative, Oedema, Diabetes Mellitus, Obesity, and Intermittent fever.

6. Calycopteris floribunda (Roxb.) Lam. ex Poir.

Anthelmintic, Colic, Headache, Dyspepsia, Diarrhea Dysentery, Laxative, Astringent, and Carminative.

7. Catharanthus roseus (L.) G.Don Diabetes, Menorrhagia, Hypotensive, Sedative,Tranquilizers and Used in waspsting

8. Clitoria ternatea $\mathrm{L}$. * Diarrhea, Asthma, Urinary Disorders, Laxative, and Demulcent.

Iphigenia indica (L.) A.Gray ex Kunth Anthelmintic, Colic, and Headache.

Ocimum tenuiflorum $\mathrm{L}$.

Respiratory Disorders, Anthelmintic, Skin diseases, Calculus, and Eye Diseases.

Tephrosia purpurea (L.) Pers. Diarrhea, Asthma and Urinary disorders, Scabies, and Eczema.

9. $\quad$ Cordia obliqua Willd.*

Azima tetracantha Lam.

Demulcent, Expectorant, Astringent, Relieve Cough, Asthma, and Used in snake-bite.

Expectorant, Cough, Asthma, and Rheumatism. 
10. Melia azedarach L.

Anthelmintic, Diuretic, Lung Disorders, Febrifuge, Cathartic, Emetic,

Emmenagogue, Stomachic, Skin diseases and Diabetes.

11. Mukia maderaspatana (L.) M.Roem. Toothache, Flatulence, Diuretic, Aperient Stomachic, and Vertigo.

12. Sida cordifolia L. Hemiplegia, Sciatica, Facial Paralysis, and Leucorrhoea.

13. Swertia chirata Buch.-Ham. ex Wall.* Anthelmintic, Diuretic, Lung Disorders, Febrifuge, Diabetes, Skin disease, Stomachic, Anti- Diarrheic, and Used in Scorpion sting.

14. Teramnus labialis (L.f.) Spreng.* Nerve diseases, Paralysis, Diarrhea, Febrifuge, Vertigo, Stomachic, and Rheumatism.

15. Toona ciliata M.Roem.

Astringent, Dysentery, Menstrual

Disorder, Ulcer, Skin diseases, and Diabetes.

${ }^{(*)}$ denotes the species sharing medicinal properties of expected and adulterant species.
Andrographis paniculata (Burm.f.) Nees

Anthelmintic, Diuretic, Lung Disorders, Febrifuge, and Diabetes.

Eclipta prostrata (L.) L.

Anemia, Spleen enlargement, Skin

troubles, and Respiratory Disorders.

Tephrosia purpurea (L.) Pers.

Diarrhea, Asthma, Urinary Disorders, Scabies, and Eczema.

Andrographis paniculata (Burm.f.) Nees Anthelmintic, Diuretic, Lung Disorders, Febrifuge, and Diabetes.

Vigna radiata (L.) R.Wilczek

Neuropathy, Diarrhea, Febrifuge, Vertigo, and Stomachic.

Azadirachta indica A.Juss.

Astringent, Anthelmintic, Ulcer, Skin diseases, and Diabetes.

\section{Sources}

1. Anonymous. The Ayurvedic Pharmacopoeia of India, $I^{\text {st }}$ Edition, Vol. I-VI. Published by Govt. of India, Ministry of Health \& Family Welfare, Dept. of Indian system of Medicine \& Homoeopathy, New Delhi (2008).

2. Yoganarasimhan, S. N. Medicinal plants of India vol.2 Tamil Nadu, Regional Research Institute (Ay.), Bangalore: Cybermedia (2000).

3. Nadkarni, A. K. Indian Materia Medica, Popular Prakashan, Bombay (1976). 